\title{
Contribution of Ekman pumping to the changes in properties and volume of the Eastern South Pacific Intermediate Water
}

\section{Contribución del bombeo de Ekman a los cambios en las propiedades y volumen del Agua Intermedia del Pacífico Sur Oriental}

\author{
Freddy Hernández-VacA ${ }^{* 1,2,3}$, Wolfgang Schneider ${ }^{3,4}$ \& José Garcés-Vargas ${ }^{5,6}$
}

${ }^{1}$ Programa de Postgrado en Oceanografía, Facultad de Ciencias Naturales y Oceanográficas, Universidad de Concepción, Casilla 160-C, Concepción, Chile.

${ }^{2}$ Dirección Oceanografía Naval, Instituto Oceanográfico de la Armada. Apartado postal: 5940 Guayaquil, Ecuador.

${ }^{3}$ Instituto Milenio de Oceanografía (IMO), Universidad de Concepción. Proyecto IC 120019

${ }^{4}$ Departamento de Oceanografía, Universidad de Concepción, Campus Concepción, Víctor Lamas 1290, Casilla 160-C, código postal: 4070043, Concepción, Chile.

${ }^{5}$ Instituto de Ciencias Marinas y Limnológicas, Facultad de Ciencias, Universidad Austral de Chile, código postal: 5090000, Valdivia, Chile.

${ }^{6}$ Centro FONDAP de Investigación en Dinámica de Ecosistemas Marinos de Altas Latitudes (IDEAL)

*freddyhernandez@udec.cl

\begin{abstract}
An update on the Eastern South Pacific Intermediate Water (ESPIW) distribution has been possible based on ARGO (Array for Real-Time Geostrophic Oceanography) data. This study comprised over 46,000 profiles obtained during 2007-2012 from an area between the western coast of South America and $150^{\circ} \mathrm{W}$, and $5^{\circ}$ and $40^{\circ} \mathrm{S}$. This information was complemented with data from the World Ocean Circulation Experiment (WOCE) P06 transects conducted in 1992 and 2010 at 32³0’S in the South Pacific Ocean. Based on a comparison of this update and data from 1990-2001, it was established that the ESPIW volume has increased by approximately 53\%. Moreover, the area occupied by ESPIW in the 2010 WOCE P06 transect was $48 \%$ higher than in 1992. Ekman pumping velocity, calculated from the wind for the time and region of ESPIW formation, showed a significant increase in Ekman pumping between 2000 and 2012. The increase in Ekman pumping from 2000 onward could explain the observed changes in ESPIW distribution (the water mass had extended zonally) and properties (salinity showed a decrease of 0.1 ). These changes could be explained as the consequence of atmospheric climate variability over the interior ocean.
\end{abstract}

KeYwORDS: South Pacific, wind stress curl, intermediate water, subduction.

\begin{abstract}
RESUMEN
Una actualización de la distribución del Agua Intermedia del Pacífico Sur Oriental (AIPSO) fue realizada con datos ARGO (Array for Real-Time Geostrophic Oceanography). Este estudio comprendió más de 46.000 perfiles obtenidos durante 2007-2012 del área entre la costa occidental de Sudamérica y $150^{\circ} \mathrm{O}$, y $5^{\circ} \mathrm{S}$ y $40^{\circ} \mathrm{S}$. Esta información se complementó con datos de las secciones P06 del World Ocean Circulation Experiment (WOCE) realizadas en 1992 y 2010 en 32 $30^{\prime} \mathrm{S}$ en el Océano Pacífico Sur. Comparando ésta actualización y los datos de 1990-2001 se estableció que el volumen del AIPSO ha aumentado aproximadamente un 53\%. Además, el área ocupada por AIPSO en el transecto WOCE P06 de 2010 fue $48 \%$ más grande que en 1992. La velocidad de bombeo Ekman, calculada a partir del viento para el tiempo y la región de la formación del AIPSO, mostró un aumento significativo en el bombeo de Ekman entre 2000 y 2012. El aumento del bombeo de Ekman desde el 2000 podría explicar los cambios observados en la distribución del AIPSO (la masa de agua se extendió zonalmente) y las propiedades (la salinidad disminuyó 0.1). Estos cambios podrían explicarse como la consecuencia de la variabilidad climática atmosférica sobre el océano interior.
\end{abstract}

Palabras clave: Pacífico Sur, rotor del esfuerzo del viento, agua intermedia, subducción. 


\section{INTRODUCTION}

The South Pacific (SP) Ocean exhibits an anticyclonic circulation around the center of the subtropical gyre. This is limited in the north by the westward-flowing Southern Equatorial Current whereas its western Australian border, the flux moves southward as the East Australian Current. At around $35^{\circ} \mathrm{S}$, the southern limit of the gyre, the SP current heads eastward, and closing the circulation cell at the eastern border it is the Humboldt Current System or the Peru-Chile Current System (Talley et al. 2011).

The subtropical region and mid-latitudes of the SP are influenced by positive wind stress curl, which leads to downward Ekman velocity (referred to as Ekman pumping) and subtropical convergence (STC) (Chereskin \& Price 2009; Stramma et al. 1995). In STC, water subducted within the main thermocline advances toward the north, upwells at the equator, and returns to the subtropics through the surface layer in the western boundary current system. This circulation is known as either the Subtropical Cell (McCreary \& Lu 1994) or the shallow meridional overturning circulation (Chen et al. 2015). Through this circulation, the properties of surface water from the subtropics are transmitted to the tropics. South of the subtropical gyre, in the Southern Ocean, there is interaction between deep and intermediate circulations, upwelling of deep waters, and freshwaterheat transfers between the ocean and the atmosphere. This transforms deep water into intermediate water and/or water within the thermocline that later forms part of the circulation managed by the wind that could return to deep convection sites (Talley 1999).

Emery and Meincke (1986) described the water masses in the SP as follows: a) upper $(0-500 \mathrm{~m})$, comprising East and West South Pacific Central Waters, Subantarctic Surface Water (SASW), Antarctic Surface Water, and East South Pacific Transition Water, and including Tropical and Subtropical Surface Water and Equatorial Subsurface Water; b) intermediate (500-1500 m), comprising Antarctic Intermediate Water (AAIW) and Eastern South Pacific Intermediate Water (ESPIW); and c) deep and abyssal $(>1500 \mathrm{~m})$, comprising Pacific Deep Water and Antarctic Bottom Water.

In the southeastern SP, the presence of surface Transition Water reflects the connection between subpolar and subtropical regions, i.e., the SASW and the East South Pacific Central Water. The physical properties of water masses such as temperature and salinity are acquired on the surface via air-sea interaction or via the mixing of two or more water masses. In the eastern SP, SASW is much fresher than in the west because of the heavy precipitation and freshwater runoff from Chilean Patagonia. Thus, this creates a low-salinity tongue that stretches from the coast of South America toward the central SP at around $45^{\circ} \mathrm{S}$ (Karstensen 2004).
Subduction induced by wind stress curl in subtropical regions (i.e., STC) is the origin of the central water masses. Subducted water from the base of the Ekman layer enters irreversibly into the permanent pycnocline. From there, it then moves toward the tropics following density gradients, which aids both the ventilation of the permanent thermocline over decades (Tomczak \& Godfrey 1994) and the sequestration of anthropogenic $\mathrm{CO}_{2}$ in the SP. According to the theories called "Mixed-layer Demon Hypothesis" (Stommel 1979) and thermocline ventilation (Luyten et al. 1983; Sprintall \& Tomczak 1993), the temperature and salinity properties of central water are acquired only in winter.

In the Eastern SP, north of the region of STC, there is an upper minimum-salinity water mass referred to as Shallow Salinity Minimum Water (Reid 1973; Tsuchiya \& Talley 1998; Karstensen 2004) or as ESPIW (Emery \& Meincke 1986). A conceptual diagram, shown in Figure 1, illustrates both the subduction process at the region of STC and the formation of central water masses. The westerly winds cause an equatorward Ekman transport (red arrow, arrowhead to the right), whereas the Ekman transport produced by the southeast trade winds is poleward (red arrow, arrowhead to the left). This leads to the creation of the STC $\left(30^{\circ}-\right.$ $35^{\circ} \mathrm{S}$ ) where SASW is subducted, forming ESPIW. Once subducted, ESPIW continues its northward path at depths of 120-220 m, moving between the saltier Subtropical Surface and Equatorial Subsurface Waters. Thus, ESPIW originates on the southeastern side of the subtropical gyre, between the coast of South America and $90^{\circ} \mathrm{W}$ (Schneider et al. 2003). Subsurface water with minimum salinity, corresponding to ESPIW, is surface water in the high latitudes with low salinity and high oxygen levels (Reid 1973). ESPIW specifically originates between $33^{\circ} \mathrm{S}$ and $38^{\circ} \mathrm{S}$ (Schneider et al. 2003) and once subducted, it continues moving toward the equator following the direction of the Humboldt Superficial Current System.

Atmospheric climate variability has an impact on the ocean. For example, intensification of coastal wind stress leads to an increase in coastal upwelling (Bakun 1990). The recent hiatus in global warming, a period during which Earth's global average surface air temperature has remained more-or-less steady since 2001 (Liu et al. 2017), has been attributed to the higher intensity of the southern trade winds in the SP during the past two decades (England et al. 2014). In the interior ocean, strengthened Ekman pumping caused by increased wind stress curl has led to intensification of Eastern Subtropical Mode Water in the SP Subtropical Gyre during the last century (Liu \& Wu, 2012). The balance between evaporation and precipitation of the SP could explain the increase in salinity in AAIW observed throughout the World Ocean Circulation Experiment (WOCE) transect at $32.5^{\circ} \mathrm{S}$, conducted in 2003 and 1992 (Schneider et al. 2005). 


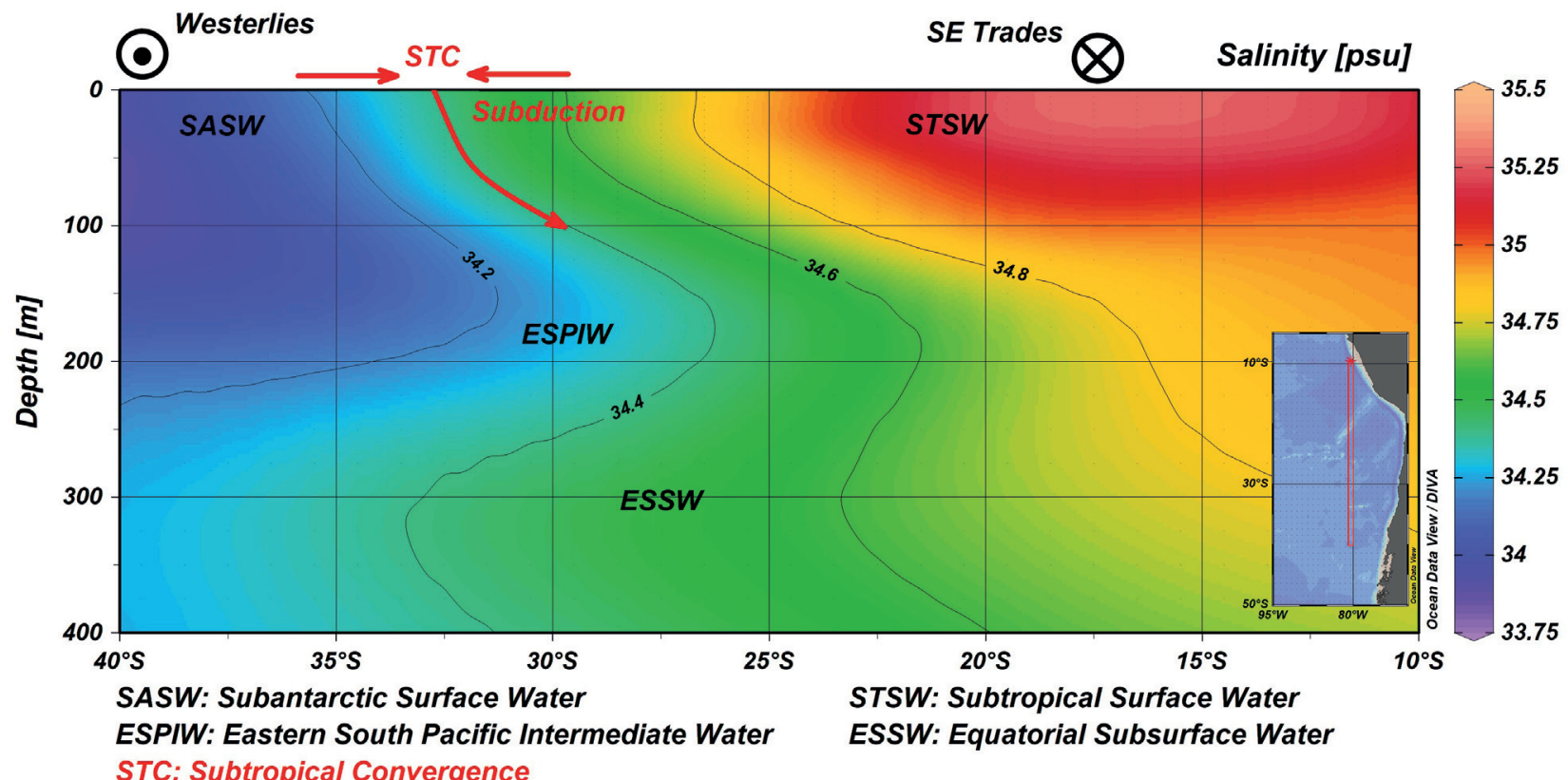

FIGURE 1. Conceptual diagram to illustrate the subduction process at the region of Subtropical Convergence (STC) and the formation of central water masses. The westerly winds cause equatorward Ekman transport (red arrows), whereas Ekman transport produced by the southeast trade winds is poleward. This leads to the creation of STC $\left(30^{\circ}-35^{\circ} \mathrm{S}\right)$ where SASW is subducted and ESPIW is formed by means of Ekman pumping. Salinity through $80^{\circ} \mathrm{W}$ is shown between $10^{\circ}-40^{\circ} \mathrm{S}$ from the surface to $400-\mathrm{m}$ depth. Annual mean salinity data used in this figure were derived from the World Ocean Atlas 2013 (https://www.nodc.noaa.gov/OC5/woa13/). / Diagrama conceptual para ilustrar el proceso de subducción en la región de la Convergencia Subtropical (CST) y la formación de masas de agua central. Los vientos del oeste causan un transporte de Ekman hacia el ecuador (flecha roja), mientras que el transporte de Ekman producido por los vientos alisios del sur-este es hacia el polo. Esto conduce al origen de la CST $\left(30^{\circ}-35^{\circ} \mathrm{S}\right)$ donde el SASW es subducida y el ESPIW se forma por medio del bombeo de Ekman. Se muestra la salinidad a lo largo del $80^{\circ} \mathrm{O}$, entre $10-40^{\circ} \mathrm{S}$ desde la superficie a $400 \mathrm{~m}$ de profundidad. Para esta figura se usaron datos del promedio anual de salinidad obtenidos de World Ocean Atlas 2013 (https://www.nodc.noaa.gov/OC5/woa13/).

The objective of this study was to reevaluate and improve the distribution and geometry of ESPIW using newer information (2007-2012) than used by Schneider et al. (2003) (1990-2001). The underlying hypothesis was that intensification of winds in the eastern SP (Weller 2015; England et al. 2014) has triggered an increase of wind stress curl and thus ESPIW production. With this aim, this study used data obtained through the Array for Real-Time Geostrophic Oceanography (ARGO) program and its monitoring network, which constitutes a major component of the ocean observation system. The massive dataset comprised over 46,000 profiles obtained during 2007-2012 from an area between the western coast of South America and $152^{\circ} \mathrm{W}$, and $5^{\circ}-40^{\circ} \mathrm{S}$. Temporal differences were established for the core features of ESPIW and these were compared with the results obtained by Schneider et al. (2003). Finally, differences in water mass properties were related to climate variability and Ekman pumping velocity. This analysis enabled an updated assessment to be made of the distribution, geometry, and salinity of ESPIW.

\section{MATERIALS AND METHODS}

SAlinity PRofiles obtained From ARgo, WOCE AND CIMAR Approximately 46,000 salinity profiles from Argo were used for this study. All the profiles were obtained within the area from the coast of South America to $150^{\circ} \mathrm{W}$, and between $5^{\circ}$ and $40^{\circ} \mathrm{S}$, from near the surface to $500 \mathrm{dbar}$. The period of interest was January 2007 to December 2012, and all profiles with a quality indicator of Flag $\mathrm{A}, \mathrm{N}=100 \%$ (all depth levels with reliable information) were employed. The vertical resolution of Argo profiles is variable; it is approximately $10 \mathrm{dbar}$ from the surface to 300 dbar, then it progresses in 20-dbar intervals until 500 dbar. Thus, an updated and improved database was established to characterize the modern geometry of ESPIW compared with the historic data (1990-2001), consisting of 779 CTD profiles, compiled by Schneider et al. (2003).

This study also used 66 salinity profiles from the surface to 500 dbar from each WOCE P06 transect conducted in 1993 and 2010. These were obtained from the coast of 
South America to $110^{\circ} \mathrm{W}$, along latitude $32.5^{\circ} \mathrm{S}$ (vertical resolution: 2 dbar). Figure 2 shows the study area, and the Argo and WOCE salinity profile distribution. Argo data were obtained from the "USGODAE ARGO GDAC Data Browser" and the WOCE data were acquired from "CLIVAR and Carbon Hydrographic Data Office." In addition, 10 profiles measured first in 1999 during the CIMAR 5 (Cruceros de Investigación Marina) expedition, conducted by CONA (Comité Oceanográfico Nacional), along $27^{\circ} 35^{\prime} \mathrm{S}$ between $79^{\circ} 35^{\prime} \mathrm{W}$ and $92^{\circ} 10^{\prime} \mathrm{W}$, and repeated in 2015 (CIMAR 21), were also employed in this study. The accuracies of the temperature, salinity, and pressure sensors on the Argo floats are $\pm 0.005^{\circ} \mathrm{C}, \pm 0.01 \mathrm{psu}$, and $\pm 5 \mathrm{dbar}$, respectively (Argo Science Team, 2000). The accuracies of the temperature and salinity data in the WOCE datasets are better than $0.003^{\circ} \mathrm{C}$ and $0.003 \mathrm{psu}$, respectively (Robertson et al. 2002), similar to the CIMAR 21 datasets (Donoso et al. 2016).

\section{ESPIW CORE AND ITS PROPERTIES}

AAIW constitutes an intermediate salinity minimum at depths around 600-800 m, whereas ESPIW represents an upper or shallow salinity minimum at depths around 200 $\mathrm{m}$ (e.g. Figure 1 at $80^{\circ} \mathrm{W}$ ). We define the ESPIW core as a layer of certain thickness with salinity that is fresher than AAIW. The presence and thickness of this layer was calculated based on each salinity profile. The layer is located at shallower depths than associated with the salinity minimum of AAIW (Figure 3). The AAIW minimum salinity was projected toward the surface and it intercepted the area of lesser salinity at shallower depths corresponding to ESPIW (Figure 3). As ESPIW spreads northward $\left(<20^{\circ} \mathrm{S}\right)$ and westward $\left(>90^{\circ} \mathrm{W}\right)$ into the SP, its salinity increases to levels slightly higher than AAIW because of vertical isopycnal mixing. Nevertheless, ESPIW remains traceable, first as a relatively shallow salinity minimum and later as a knee-shaped curve in the T-S diagram in the sigma-t range typical of ESPIW.

\section{Temporal CHANGES IN ESPIW}

The temporal changes in the spatial distribution (upper limit and thickness) and volume of the ESPIW's core were obtained by comparing modern and historic results in the area between the coast of Chile and $90^{\circ} \mathrm{W}$, and $20^{\circ}-40^{\circ} \mathrm{S}$, i.e., where the salinity of ESPIW is less than that of AAIW. The modern data of this geographic area comprised 8,700 ARGO profiles showing the core structure of ESPIW between 2007 and 2012. The historic data of Schneider et al. (2003) comprised 149 CTD profiles from 1990-2001. Differences in the extension and salinity of ESPIW were also established throughout the larger study area. Extension is represented by the average salinity of each profile in the density range of $\sigma_{t}$, between 25.75 and $26.25 \mathrm{~kg} / \mathrm{m}^{3}$ the sigma-t range estimated for its core. Additionally, ESPIW's difference in relative location was estimated for 1992 and 2010 , represented by the 34.28 isohaline, in each section of the WOCE P06 transect along $32.5^{\circ} \mathrm{S}$ from the coast of Chile to $110^{\circ} \mathrm{W}$.

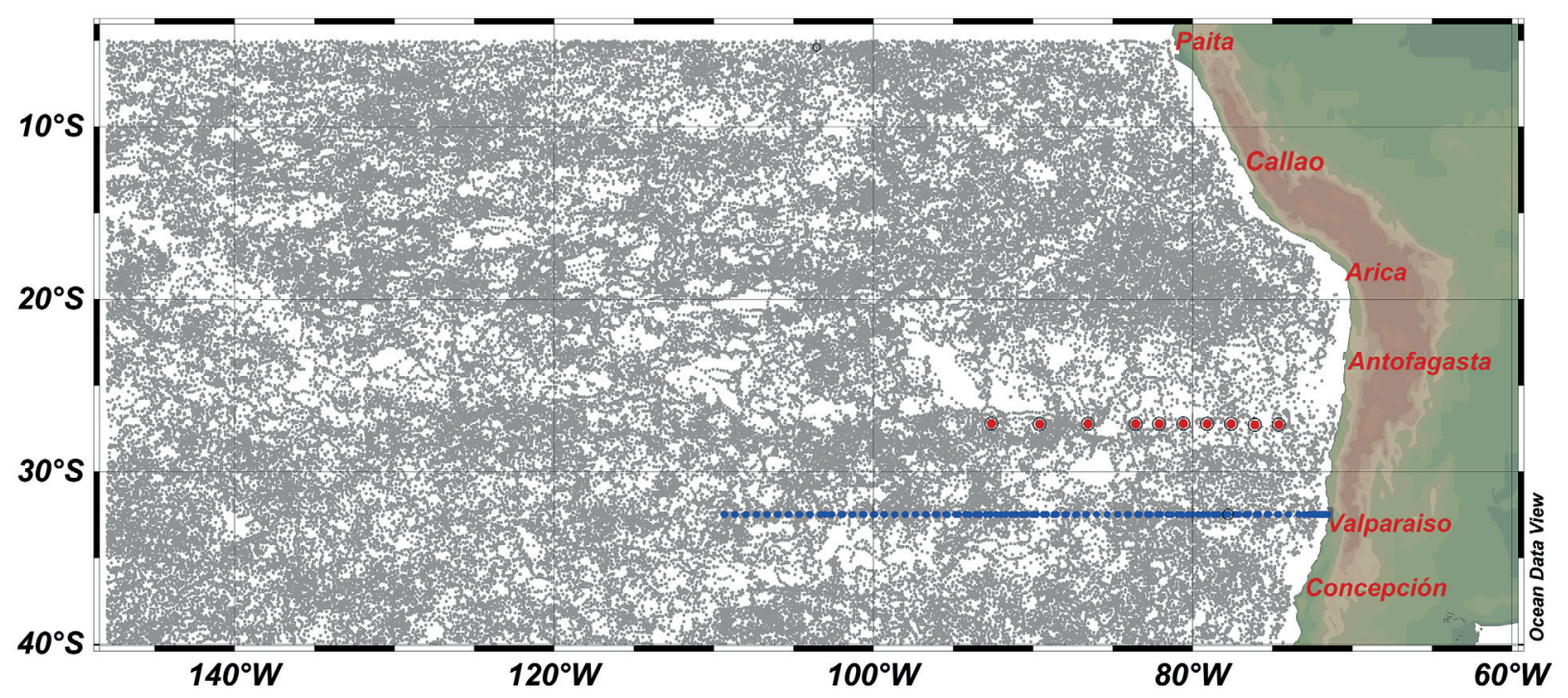

FIGURE 2. Study Area: South Pacific Ocean. Grey dots are Argo profiles obtained during 2007-2012. Blue dots throughout $32^{\circ} 30^{\prime}$ S indicate WOCE P06 transect and stations used in this study (first performed in 1993 and repeated in 2010). Red dots throughout $27^{\circ} \mathrm{S}$ indicate CIMAR 5 transect and stations used in this study (first performed in 1999 and repeated in 2015). / Área de studio. Océano Pacífico Sur. Puntos grises corresponden a perfiles Argo obtenidos durante 2007-2012. Los puntos azules a lo largo del $32^{\circ} 30^{\prime} \mathrm{S}$ indican la transecta WOCE P06 y las estaciones usadas en este estudio (realizada primero en 1993 y repetida en 2010). Los puntos rojos a lo largo de $27^{\circ} \mathrm{S}$ indican la transecta CIMAR 5 y las estaciones usadas en este estudio (realizada primero en 1999 y repetida en 2015). 
EKMAN PUMPING VELOCITY

Five sources of monthly mean wind products, representing winds at $10 \mathrm{~m}$ above the ocean surface, were used for the computation of Ekman pumping velocity. These comprised satellite derived data: 1) ERS1/2 AMI, provided by IFREMER /CERSAT, and 2) QuikSCAT obtained from Centre d'Exploitation et de Recherche Satellitaire d'Archivage et de Traitement (CERSAT) at the Institut Francais de Recherche pour l'Exploitation de la Mer (IFREMER); and model data: 3) ERA-Interim, 4) Navy Operational Global Atmospheric Prediction System (NOGAPS) model "Fleet Numerical Meteorology and Oceanography Center" (FNMOC), and 5) Reanalysis data from the National Center for Environmental Prediction (NCEP). Details of their resolutions, available periods, and products are listed in Table 1.

Ekman pumping velocity (EP) was calculated according to Tomczak and Godfrey (1994) using the following equation:

$$
\mathrm{EP}=\frac{\text { Curl }}{\rho_{\text {sea water } \mathrm{f}}} ; \quad \text { Curl }=\frac{\partial \tau_{y}}{\partial \mathrm{x}}-\frac{\partial \tau_{x}}{\partial \mathrm{y}} ; \quad \text { (Equation 1) }
$$

where $\rho_{\text {sea water }}=1023 \mathrm{~kg} / \mathrm{m}^{3}$, which is the reference density of seawater, $\mathrm{f}$ is the Coriolis parameter $(\mathrm{f}=2 \Omega \sin \varnothing$, where
$\Omega=7.29 \times 10^{-5}(\mathrm{rad} / \mathrm{s})$ is earth's angular velocity and $\varnothing$ is latitude, and $\tau_{\mathrm{y}}$ and $\tau_{\mathrm{x}}$ are the meridional and zonal components of wind stress, respectively. The latter two parameters are calculated from:

$$
\tau_{y}=\mathrm{C}_{\mathrm{D}} \rho_{\mathrm{air}} \mathrm{v} \mathrm{U}_{10} \quad \tau_{x}=\mathrm{C}_{\mathrm{D}} \rho_{\text {air }} \mathrm{u} \mathrm{U}_{10} \text { (Equation 2) }
$$

where $C_{D}$ is the drag coefficient (0.0013, used in NCEP and ERA Interim reanalysis), also we use wind stress data, wich is computed utilising ERS-1, ERS-2 and QuikSCAT observations, and following the recommendations of Smith, (1988) to assign $\mathrm{C}_{\mathrm{D}}$ values of $1 \times 10^{-3}$ for wind speeds between $2-5 \mathrm{~m} / \mathrm{s}$, and $2 \times 10^{-3}$ for wind speeds up to $24 \mathrm{~m} / \mathrm{s}$, $\rho_{\text {air }}$ is the air density $\left(1.2 \mathrm{~kg} / \mathrm{m}^{3}\right), \mathrm{u}$ and $\mathrm{v}$ are the zonal and meridional wind components, respectively, and $\mathrm{U}_{10}$ is the magnitude of the wind $10 \mathrm{~m}$ above the ocean surface. ERS1/2 AMI, QuikSCAT, and FNOMC already provide the wind stress curl from which the Ekman pumping velocity was calculated.

Linear trends of series of regionally and temporally averaged $\overline{E P}$ were analyzed for two periods: 1991-2000 and 2000-2012. The first was used by Schneider et al. (2003) for their first estimation of the properties and geometry of ESPIW. Here, $\overline{E P}$ is the EP average in the region and time
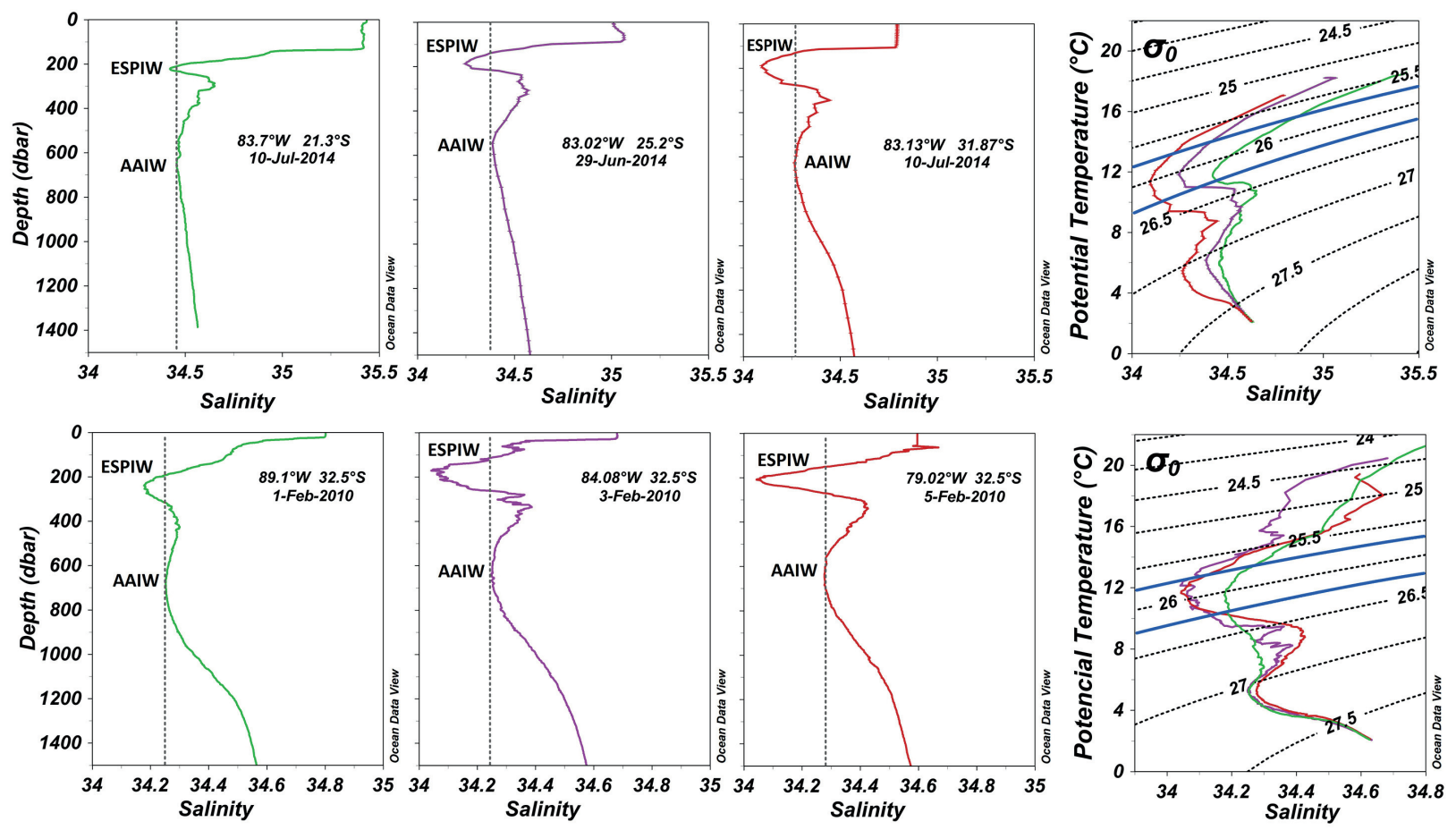

FIGURE 3. Salinity profiles and T-S diagrams. Upper panels: Argo data showing ESPIW core and depicting its meridional variation. Lower panels: WOCE P06 transect data with ESPIW core and depicting its zonal variation. Blue dotted lines in T-S diagrams show ESPIW core limits: $\sigma_{\mathrm{t}}$ between 25.75 and $26.25 \mathrm{~kg} / \mathrm{m}^{3}$. / Perfiles de salinidad y diagramas T-S. Panel superior: Datos Argo mostrando el núcleo del ESPIW que representa su variación meridional. Panel inferior: Datos de la transecta WOCE con el núcleo del ESPIW que representa su variación zonal. La línea punteada azul en los diagramas T-S muestra los límites del núcleo del ESPIW: $\sigma_{\mathrm{t}}$ entre 25,75 y 26,25 kg/m³. 
of formation of ESPIW, i.e., $82.5^{\circ}-76^{\circ} \mathrm{W}$ and $30^{\circ}-39^{\circ} \mathrm{S}$, and August-September, respectively (Karstensen 2004; Luyten et al. 1983; Schneider et al. 2003). For each average, 70, 240, 12, 60, and 112 grid points from FNMOC, QuikSCAT, NCEP, ERS, and ERA-Interim, respectively, were used owing to the different horizontal resolutions of the five databases. The coastal zone was disregarded for favoring upwelling (Letelier et al. 2009) and the southern and northern limits were established in relation to the minimum surface salinity values indicating the outcrop region of ESPIW.

TABLE 1. Characteristics of wind products. / Características de los productos de vientos.

\begin{tabular}{|c|c|c|c|c|}
\hline SOURCE & Period & $\begin{array}{l}\text { RESOLUTION } \\
\text { (Longitude } \times \\
\text { Latitude) }\end{array}$ & DOWNLOAD SITE & AVAILABLE PRODUCTS \\
\hline ERS 1/2-AMI & $1991-2000$ & $1^{\circ} \times 1^{\circ}$ & Ifremer/CERSAT & $\begin{array}{l}\text { Zonal and meridional wind } \\
\text { components } \\
\text { Wind stress }\end{array}$ \\
\hline QuikSCAT & 2000-2009 & $0.5^{\circ} \times 0.5^{\circ}$ & $\begin{array}{l}\text { Centre ERS d'Archivage et de Traitement } \\
\text { (CERSAT) } \\
\text { (http://www.ifremer.fr/cersat/en/index.htm) }\end{array}$ & $\begin{array}{l}\text { Zonal and meridional wind } \\
\text { components } \\
\text { Wind stress and wind stress curl }\end{array}$ \\
\hline FNMOC & $2000-2012$ & $1^{\circ} \times 1^{\circ}$ & $\begin{array}{c}\text { http://coastwatch.pfeg.noaa.gov/erddap/ } \\
\text { search/index.html?searchFor=erdlasFnWind }\end{array}$ & $\begin{array}{l}\text { Zonal and meridional wind } \\
\text { components } \\
\text { Wind stress and wind stress curl }\end{array}$ \\
\hline ERA-Interim & 1991-2012 & $0.75^{\circ} \times 0.75^{\circ}$ & $\begin{array}{c}\text { http://apps.ecmwf.int/datasets/data/interim- } \\
\text { full-daily/levtype }=\mathrm{sfc} /\end{array}$ & $\begin{array}{l}\text { Zonal and meridional wind } \\
\text { components }\end{array}$ \\
\hline NCEP & 1991-2012 & $2.5^{\circ} \times 2.5^{\circ}$ & $\begin{array}{c}\text { https://www.esrl.noaa.gov/psd/data/gridded/ } \\
\text { data.ncep.reanalysis.htm }\end{array}$ & Zonal and meridional wind \\
\hline
\end{tabular}

\section{RESULTS}

\section{MODERN EXTENSION OF ESPIW AND SALINITY DECREASE}

The core of ESPIW, with salinity less than that of AAIW, inhabits the eastern portion of the SP subtropical gyre north of the region of STC and it occupies the depth range of 100-300 m; therefore, it becomes part of the general gyre circulation. Once part of this circulation, ESPIW mixes gradually with overlying Subtropical and underlying Equatorial Subsurface Water, both of which are saltier; thus, it starts to lose its signature feature of being less saline than AAIW (Schneider et al. 2003). Nevertheless, it sustains a traceable relative upper salinity minimum in its typical sigma-t density range of $25.75-26.25 \mathrm{~kg} / \mathrm{m}^{3}$. Figure 3 , as an example, shows salinity profiles and T-S diagrams from Argo (above) and WOCE P06 (below), and the spatial variability of the ESPIW core is highlighted in the meridional (above) direction as well as in the zonal (below) direction. In the upper row (meridional from north to south), the profile core thickness of ESPIW diminishes northward from $146 \mathrm{~m}$ at $31.87^{\circ} \mathrm{S}$ to $25 \mathrm{~m}$ at $21.33^{\circ} \mathrm{S}$, while its upper limit deepens from 130 to $210 \mathrm{~m}$ at the same latitudes. The lower row profiles (zonal from west to east) show the ESPIW core thickness varies between 119 and $155 \mathrm{~m}$, and its upper limit varies between depths of 105 and $191 \mathrm{~m}$. In the T-S diagrams of both rows, the minimum salinities at the lesser depths (ESPIW core) have values in the $\sigma_{t}$ range of $25.75-26.25 \mathrm{~kg} / \mathrm{m}^{3}$.

The geographic pattern of average salinity within this specific density range allows the extension of ESPIW to be traced and the limit of its influence in communicating SASW to intermediate depths of the tropical SP to be determined. This new geographic pattern of average salinity within the ESPIW density range together with the historic pattern is presented in Figure 4. The westward extension of ESPIW is evident in the historic pattern established using the 779 CTD profiles (Schneider et al. 2003); however, it is defined with much more reliability in the modern by the incorporation of the 46,000 ARGO profiles. ESPIW can be traced up to $150^{\circ} \mathrm{W}$ in the tropical SP. Salinity changes in ESPIW were established by comparing the geographic positions of the modern salinity isolines with their historic counterparts. For example, the modern 34.7 isohaline coincides with the historic 34.8 isohaline, and the modern 34.9 isohaline is found overlying the historic 35.0 isohaline. This suggests that a decrease of 0.1 in salinity has occurred over the entire domain (Figure 4). A repeated hydrographic transect, October 1999 and October 2015 (CIMAR 5 and 
21), between the coastal Chilean city of Caldera and Easter Island along latitude $27^{\circ} \mathrm{S}$ crossed ESPIW and showed the very same drop of 0.1 in salinity in the density range of this water mass based on the averages obtained for 2015 and 1999, with standard deviations 0.281 and 0.305 respectively.

TEMPORAL CHANGES IN GEOMETRY OF ESPIW'S CORE

The modern Argo database (2007-2012) allowed an update to the geometry of the ESPIW core, with salinity less than that of the deeper AAIW, in more detail and for a much larger geographic region than in Schneider et al. (2003). The newly computed origin of the ESPIW core is represented by the blue line ( $0-\mathrm{m}$ depth of its upper limit) in Figure 5a. This line represents where subduction begins, i.e., between $100^{\circ} \mathrm{W}$ and the coast of Chile, and south of $35^{\circ} \mathrm{S}$ at its western side, and it follows a northeasterly direction toward the coast of South America $\left(30^{\circ} \mathrm{S}\right)$. From the origin of subduction, the upper limit of this water mass generally deepens toward the northwest until $325 \mathrm{~m}$, where the core becomes indistinguishable equatorward of $25^{\circ} \mathrm{S}$ (Figure 5a). In other words, the salinity of ESPIW is higher than AAIW but ESPIW maintains the properties of a relative upper minimum salinity at a shallower depth than AAIW (see Figure 3). Once SASW has been subducted to form ESPIW, it joins the subtropical gyre circulation.

The thickness of the ESPIW core, based on Argo data, varies between 25 and $250 \mathrm{~m}$ (Figure 5b). From the subduction line of ESPIW toward the north, its core thickness varies meridionally, diminishing toward the north and fading at around $15^{\circ} \mathrm{S}$, where thicknesses of $<25 \mathrm{~m}$ were measured. This meridional gradient is more abrupt in the west $\left(100^{\circ} \mathrm{W}\right)$ than to the east of $85^{\circ} \mathrm{W}$. The core has a thickness of $>50 \mathrm{~m}$ up to $23^{\circ} \mathrm{S}$ in the eastern portion; however, the equivalent is only up to $32^{\circ} \mathrm{S}$ to the west of $85^{\circ} \mathrm{W}$. Thus, in the western extreme, the thickness of the core decreases from 250 to $50 \mathrm{~m}$ over approximately $3^{\circ}$ latitude, whereas it changes from 250 to $100 \mathrm{~m}$ over $6^{\circ}$ latitude at $85^{\circ} \mathrm{W}$. South of the subduction line, by definition, there is no subsurface upper salinity minimum but the surface water nevertheless shows salinities less than AAIW. This is considered not to be ESPIW but SASW instead (Figure 5b inset).

Temporal changes in the upper base, thickness, and volume were analyzed regarding the distribution of the ESPIW core by comparison of the modern results with those obtained by Schneider et al. (2003), who used data gathered between the coast of Chile and $90^{\circ} \mathrm{W}$, and $20^{\circ}$ $38^{\circ} \mathrm{S}$ from 1990-2000 (red box in Figure 5b). The modern geographic distribution of the core's upper depth, indicated by the contour lines in Figure 5a, was compared with the distribution of the historic upper depth of the core presented by Schneider et al. (2003). The modern upper depth of the ESPIW core maintains its distribution in relation to historic recordings (Figure 5a). However, the geographic patterns of the thickness of the core present nonhomogenous temporal changes, i.e., a differential increase in thickness illustrated by the movement of the 50 and 100 $\mathrm{m}$ contour lines (Figure $5 \mathrm{~b}$ ). Specifically, the 50-m contour is displaced toward the north by about $6^{\circ}$ at its western

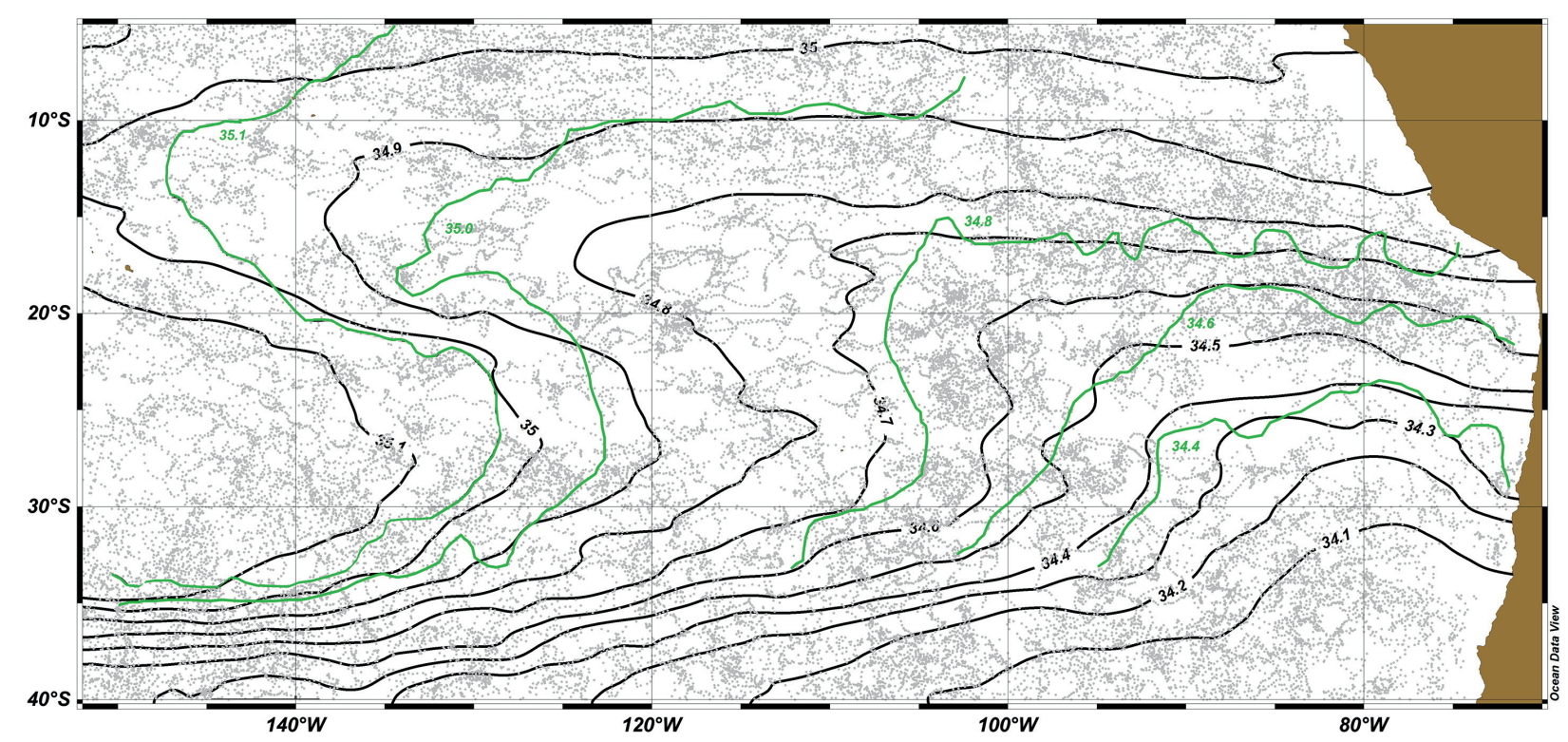

FIgURE 4. ESPIW extension. Contours of average salinity in the $\sigma_{\mathrm{t}}$ range between 25.75 and $26.25 \mathrm{~kg} / \mathrm{m}^{3}$. Modern results: black contour lines. Historic results: green contour lines. Approximately 46,000 Argo profiles obtained during 2007-2012 were considered (gray dots). / Extensión del ESPIW. Contornos del promedio de salinidad en el rango de $\sigma_{\mathrm{t}}$ entre 25,75 y $26,25 \mathrm{~kg} / \mathrm{m}^{3}$. Resultados actuales: líneas de contornos color negro. Resultados históricos: líneas de contornos de color verde. Se consideraron aproximadamente 46.000 perfiles Argo durante 2007-2012 (puntos grises). 
end and by less than $1^{\circ}$ at $79^{\circ} \mathrm{W}$, whereas further east, the modern 50-m contour coincides with its historic counterpart (Figure 5b). Furthermore, the 100-m thickness contour is displaced toward the north by approximately $3^{\circ}$. The core of ESPIW, with thickness of $>25 \mathrm{~m}$, is also present at more equatorward latitudes $\left(\leq 20^{\circ} \mathrm{S}\right)$ not reported by Schneider et al. (2003). This indicates an expansion of this water mass toward the north. Variations of the core's geometry have led to a $53 \%$ increase in occupied volume. A similar increase was observed in the temporal change of the area occupied by ESPIW (isohaline of 34.28) in repeated hydrographic transects at $32.5^{\circ} \mathrm{S}$ in January-February 2010 and May 1992. Salinity from the coast to $110^{\circ} \mathrm{W}$ and from the surface to the depth of $500 \mathrm{~m}$ is depicted in Figure 6. The upper salinity limit of ESPIW is characterized by the 34.28 isohaline that delimits the lower salinities that correspond to ESPIW. In 2010 , it was deeper by $100 \mathrm{~m}$ and it extended almost $10^{\circ}$ further west than in 1992, comprising an increase in area of $48 \%$; however, the absolute minimal salinity within the core remained unchanged (Figure 6).

EVOLUTION OF EKMAN PUMPING VELOCITY 1991-2012

Here, we concentrate on establishing the atmospheric variability by means of deduced from the five wind products analyzed for the historic and modern periods over the ESPIW formation region $\left(30^{\circ}-39^{\circ} \mathrm{S}, 82.5^{\circ}-76^{\circ} \mathrm{W}\right.$; Figure 5a) during austral winter. During 1991-2000, a decrease in magnitude was observed, as deduced from NCEP, ERA-Interim, and ERS wind products, which was unfavorable for subduction (Figure 7). Conversely, magnitude increased during 20002012, favoring subduction (as deduced from NCEP, ERAInterim, QuikSCAT, and FNMOC wind products) (Figure 7). For NCEP, ERA-Interim, and ERS products, the linear trends of Ekman pumping velocity in the historic period were $0.8,2.6$, and $2.7 \mathrm{~m} /$ year per year, respectively, i.e., decreasing by half (please note that Ekman velocity is negative). Most of the historic data used to estimate the geometry of ESPIW were from 1995-2000. In this latter episode, Ekman pumping velocity was about $-25 \mathrm{~m} /$ year when combining the three wind products. From 2000 onward, Ekman pumping intensified and the 1991 levels were reestablished by 2012; deduced from NCEP, ERAInterim, QuikSCAT, and FNMOC products, the gains were $-1.1,-1.2,-2.7$, and $-1.0 \mathrm{~m} /$ year per year, respectively. The modern dataset for ESPIW analysis consisted of data from 2007-2012. In this period, the mean Ekman pumping velocity amounted to around $-35 \mathrm{~m} /$ year, i.e., $10 \mathrm{~m} /$ year faster than during 1995-2000.
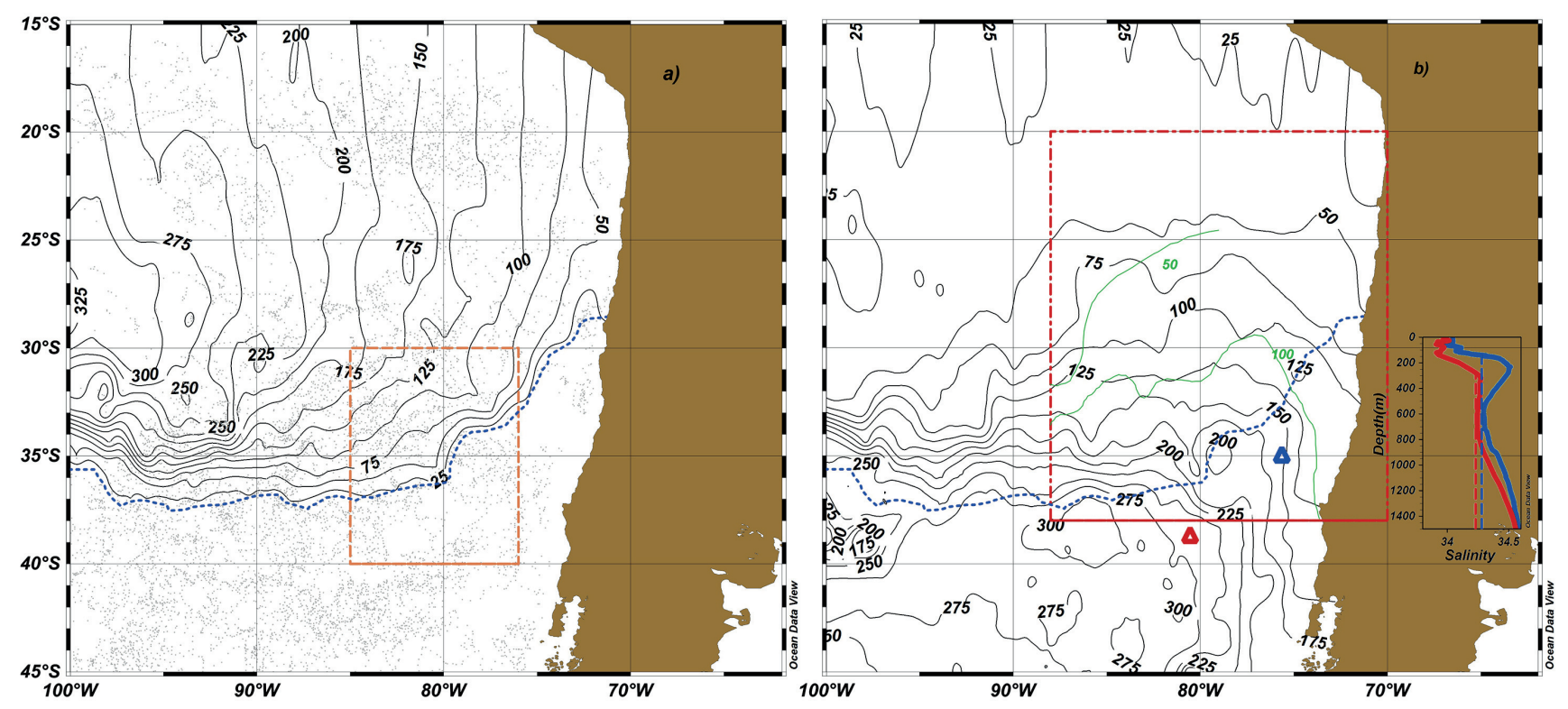

FIGURE 5. Geometry of ESPIW core. a) Depth of upper limit of ESPIW core (m). Gray dots indicate Argo profile positions. Brown rectangle marks ESPIW formation region considered for EP calculation. Dotted blue line shows ESPIW core upper limit 0, where lower salinity water is ready for subduction. b) ESPIW core thickness (m). Modern results (black contour lines) and historic results (green contour lines). Salinity profiles at red and blue triangles (south of the limit of ESPIW) display SASW with less salinity than AAIW, which later forms part of ESPIW; inset in b). / Geometría del núcleo del ESPIW. a) Profundidad del límite superior del ESPIW (m). Los puntos grises indican la posición de los perfiles Argo. El rectángulo café marca la región de formación del ESPIW considerada en el cálculo del EP. La línea punteada azul muestra el límite superior 0 del núcleo del ESPIW, donde el agua de menor salinidad está lista para la subducción. b) Espesor del núcleo del ESPIW (m). Resultados actuales (líneas de color negro) y resultados históricos (líneas de color verde). Perfiles de salinidad en triángulos azul y rojo (al sur del límite del ESPIW) muestra el SASW con menor salinidad que el AAIW, la cual luego forma parte del ESPIW; recuadro en b). 


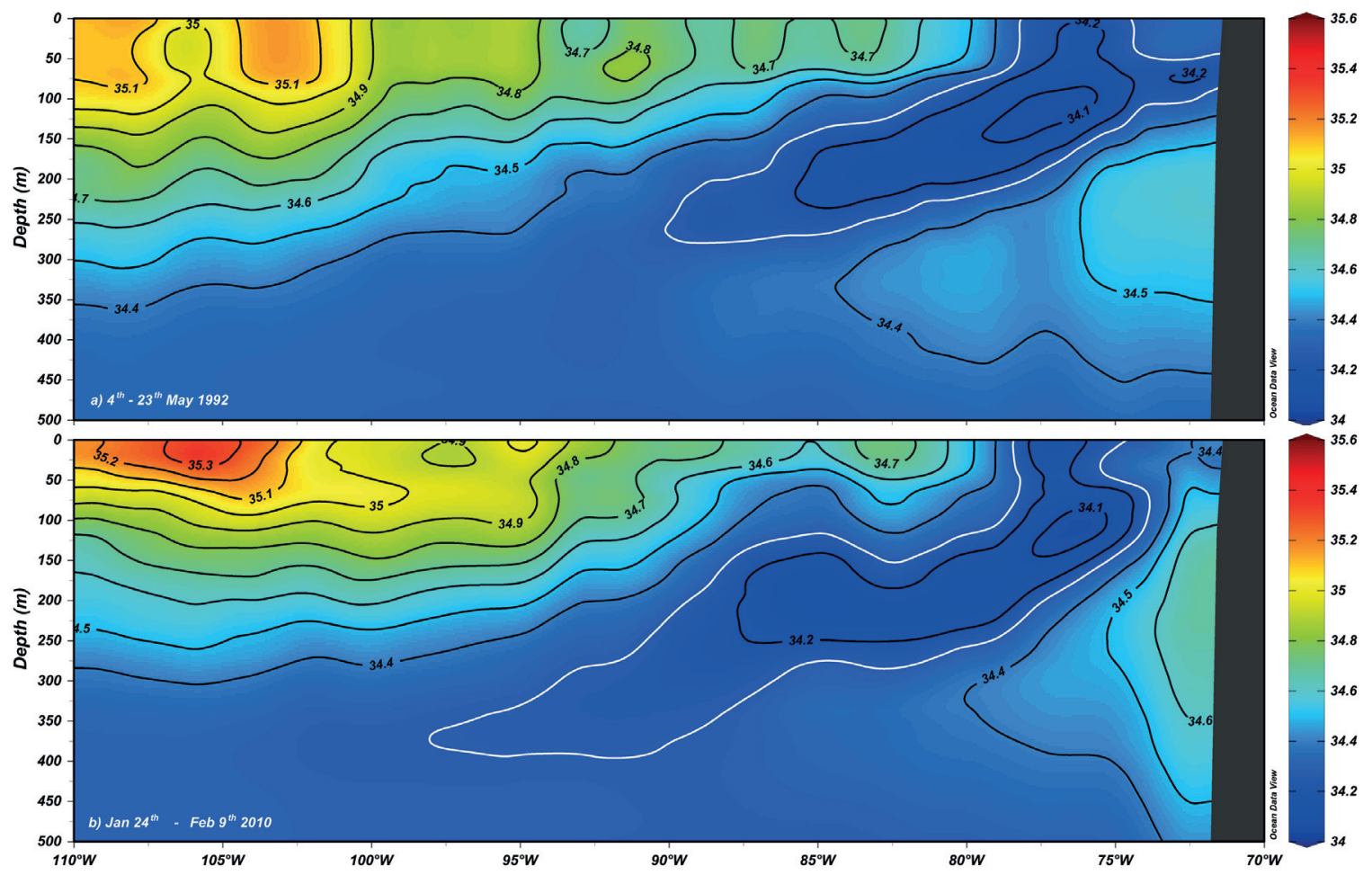

FIGURE 6. Salinity section throughout WOCE P06 transect at $32.5^{\circ} \mathrm{S}$ : a) 1993 and b) 2010 . White contour is 34.28 isohaline, which is the upper limit of the ESPIW core. / Sección de salinidad a lo largo de la transecta WOCE P06 en 32,55: a) 1993 y b) 2010 . El contorno blanco es la isolínea de 34,28, la cual es el límite superior del núcleo de ESPIW.
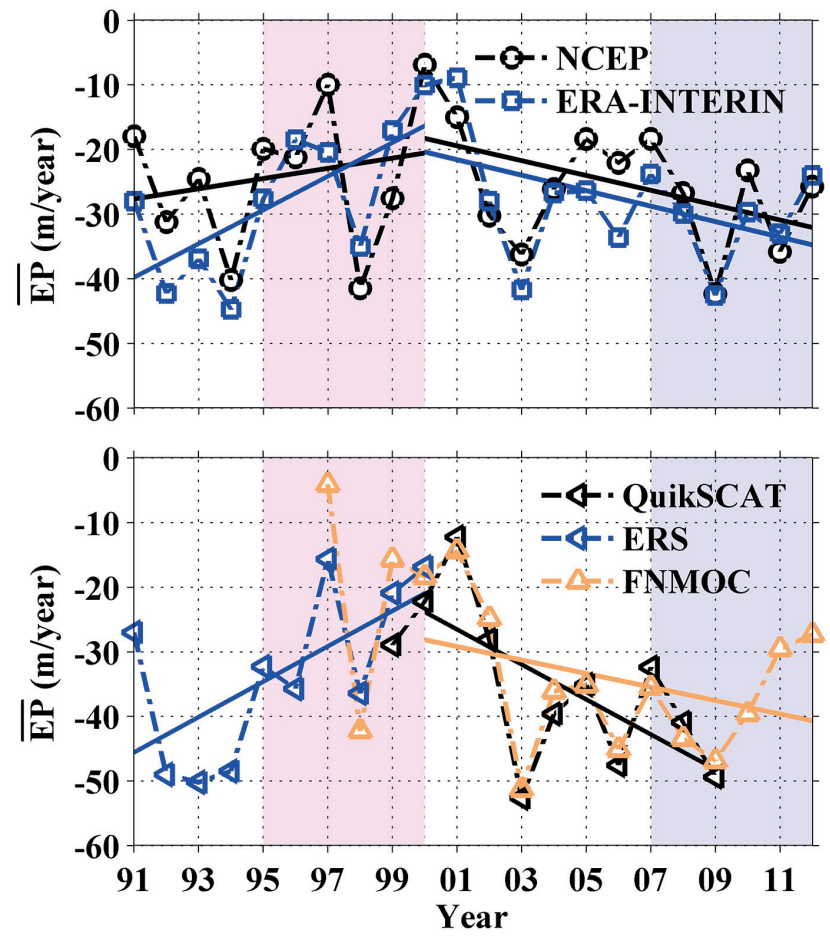

FIGURE 7. $\overline{\mathrm{EP}}$ time series. Based on ESPIW formation region with different wind products within the region (Figure 5, brown rectangle) and formation time (August-September). The total period was divided into two subperiods: 1991-2000 and 20002012. In the $\overline{\mathrm{EP}}$ time series of each wind product the linear trend in shown. Most of the data used to evaluate the historic and modern geometry of ESPIW were obtained from 1995-2000 and 2007-2012. / Serie de tiempo $\overline{\mathrm{EP}}$. Basado en la región de formación del ESPIW con diferentes productos de viento dentro de la región (Figura 5, rectángulo café) y tiempo de formación (agosto-septiembre). El periodo total fue dividido en dos sub-periodos: 1991:2000 y 20002012. La tendencia lineal de cada producto de viento es mostrada en cada serie de tiempo de $\overline{\mathrm{EP}}$. La mayoría de los datos usados para evaluar la geometría del ESPIW fueron obtenidos de los periodos $1995-2000$ y $2007-2012$. 


\section{DISCUSSION}

The ESPIW reduction in salinity could be explained by an increase in the precipitation-evaporation (P-E) balance and/or the presence of less saline water in the region of ESPIW formation, i.e., SASW. Analysis of the P-E balance using ERA-Interim data for the region $42.5^{\circ}-48.0^{\circ} \mathrm{S}, 76^{\circ}$ $85^{\circ} \mathrm{W}$ (SASW before being subducted) during 2000-2012 revealed only a small nonsignificant positive statistical trend. Analysis based on differences between early Argo and 1990s hydrographic data and changes in sea surface height suggested the circulation of the SP subtropical gyre increased during 1993-2004 (Roemmich et al. 2007). This intensification of the gyre circulation reduced salinity in the upper $200 \mathrm{~m}$ of the water column in the eastern SP, along $32^{\circ} 30^{\prime} \mathrm{S}$ by 0.1 , via amplified transport of fresher SASW from higher to middle latitudes (Schneider et al. 2007). Equatorward transport in the eastern portion of the SP gyre continued to increase through 2014 (Roemmich et al. 2016); thus, the supply of fresher SASW toward the region of ESPIW formation could have contributed to the observed drop in ESPIW salinity. General freshening (1950-2008) in the outcrop regions of Pacific Central Water was deduced by Durack and Wijffels (2010), which could explain the freshening of subsurface central water. The ESPIW upper limit of the core maintained the distribution and ranges proposed by Schneider et al. (2003), and indicated that the position of the subtropical gyre was sustained despite the strengthening of its circulation during the last two decades (Roemmich et al. 2016).

Differences were found in the magnitude and the gain of derived from the five wind products for both 1991-2000 and 2000-2012; however, the patterns (variability and slopes) of their time series were consistent throughout both periods. We attribute the differences in magnitude to the nature of the data (either from models or from satellite-borne scatterometer measurements), validation procedures against different observational data, and to the different horizontal resolutions of the five wind products used.

Change in the Coriolis parameter with latitude and principally, spatio-temporal variations in wind stress affect EP. Our results agree with Ancapichún and GarcésVargas (2015), who demonstrated intensification of the Southeast Pacific anticyclone from 2000 onward, which was accompanied by an increase in Ekman pumping along the northern and central coast of Chile. Additionally, the trend of change from 2000 onward matches the beginning of a decade of deceleration in sea surface warming on the global scale, most likely due to an increase of the SP trade winds (England et al. 2014). An acceleration of downward EP velocity is favorable for amplified ESPIW formation (Karstensen 2004; Schneider et al. 2003; Tsuchiya and Talley 1998), and the $\overline{E P}$ trend from 2000 onward leads us to the explanation of the increase in volume and area of ESPIW, which in turn contributed to the ventilation of areas of the SP of intermediate depth. Similarly, Pérez et al. (2000) associated variable wind stress curl with variability in the ventilation of North East Atlantic Central Water, while Waugh (2014) associated it with the descent in age of Subantarctic and Subtropical Mode Waters.

This study focused on ESPIW formation and it did not consider interactions proposed by Reid (1973) to explain the occasional presence of ESPIW north of $12^{\circ} \mathrm{S}$. Characteristics such as lateral exchanges between water masses brought by the south equatorial current, equatorial countercurrent, and interaction of surface low salinity water north of the equator and high salinity southwest of the equator will be left for future investigations.

\section{CONCLUSIONS}

This study revealed the greater thickness and volume, reduced salinity, and extended area and depth of ESPIW. This could contribute to intermediate depth ventilation, and to increases in the temperature and the sequestration of anthropogenic $\mathrm{CO}_{2}$ of the interior ocean at the scale of climatic variability. The detected changes were produced during a decade of accelerated trade winds over the Pacific Ocean and a halt of global ocean surface warming initiated in 2000. The findings demonstrate how climate variability immediately affects the formation of oceanic water masses.

\section{ACKNOWLEDGMENTS}

Freddy Hernández thanks the Secretaria de Educación Superior, Ciencia, Tecnología e Innovación (SENESCYT) and the Instituto Oceanográfico de la Armada (INOCAR) del Ecuador for scholarship contract No 20090315. Argo data were collected and made freely available by the International Argo Program and the national programs that contribute to it (http://www.argo.ucsd.edu, http://argo. jcommops.org). The Argo Program is part of the Global Ocean Observing System. WOCE data were obtained from the CLIVAR and Carbon Hydrographic Data Office (https:// cchdo.ucsd.edu/). In addition, profiles measured during the CIMAR 5 and 21 (Cruceros de Investigación Marina) expeditions conducted by CONA (Comité Oceanográfico Nacional) were employed in this study.

\section{REFERENCES}

AnCAPichún, S., Garcés-Vargas, J. 2015. Variability of the Southeast Pacific Subtropical Anticyclone and its impact on sea surface temperature off north-central Chile. 
Ciencias Marinas 41: 1-20. doi: http://dx.doi.org/10.7773/ cm.v41i1.2338.

Argo Science Team 2000. Report of the Argo Science Team Second Meeting. Proc. Argo Science Team Second Meeting, Southampton Oceanography Centre, Southampton, U.K., $35 \mathrm{pp}$.

BAKUn, A. 1990. Global climate change and intensification of coastal ocean upwelling. Science 247(4939): 198-201. doi: 10.1126/science.247.4939.198.

Carbon Hydrographic Data Office. 2015. URL: https://cchdo. ucsd.edu/ (Accessed: January 15, 2015).

Chen, H.C., Sui, C.H., Tseng, Y.H., Huang, B.H. 2015. An analysis of the linkage of Pacific subtropical cells with the recharge-discharge processes in ENSO evolution. Journal of Climate 28: 3786-3805.

Chereskin, T.K., Price, J.F. 2009. Ekman transport and pumping. In: Steele, J., Thorpe, S., Turekian, K. (Eds) Encyclopedia of Ocean Sciences. Academic Press.

Donoso, D., Hernandez, F., Navarro, E., Schneider, W. 2016. Cambio de las propiedades hidrográficas en la columna de agua entre Caldera e Isla de Pascua (2015-1999). Taller de resultados preliminares Crucero CIMAR 21 "Islas Oceánicas" 22 de noviembre de 2016 Valparaiso, Chile.

Durack, P.J., WiJfFels, S.E. 2010. Fifty-year trends in global ocean salinities and their relationship to broad-scale warming. Journal of Climate 23: 4342-4362. doi: 10.1175/2010JCLI3377.1.

EMERY, W.J., MEINCKE, J. 1986. Global water masses: summary and review. Oceanologica Acta 9: 383-391.

England, M.H., Mcgregor, S., Spence, P., Meehl, G.A, Timmermann, A., Cai, W., Gupta, A.S., Mcrhaden, M.J., Purich, A., Santoso, A. 2014. Recent intensification of wind-driven circulation in the Pacific and the ongoing warming hiatus. Nature Climate Change 4: 222-227. doi: 10.1038/nclimate2106.

Karstensen, J. 2004. Formation of the South Pacific shallow salinity minimum: A Southern Ocean pathway to the tropical Pacific. Journal of Physical Oceanography 34: 2398-2412.

Letelier, J., Pizarro, O., Nuñez, S. 2009. Seasonal variability of coastal upwelling and the upwelling front of central Chile. Journal of Geophysical Research 114. doi: 10.1029/2008JC005171.

Liu, C.Y., Wang, Z.M., Li, B.R., Cheng, C., XIA, R.B. 2017. On the response of subduction in the South Pacific to an intensification of westerlies and heat flux in an eddy permitting ocean model. Advances in Atmospheric Sciences 34: 521-531.

Liu, L.L., Huang, R.X. 2012. The global subduction/obduction rates: Their interannual and decadal variability. Journal of Climate 25: 1096-1115. doi: 10.1175/2011JCLI4228.1.

Luyten, J.R., Pedlosky, J., Stommel, H. 1983. The ventilated thermocline. Journal of Physical Oceanography 13: 292309.

McCreary JR., J.P., Lu, P. (1994). Interaction between the subtropical and equatorial ocean circulations: The subtropical cell. Journal of Physical Oceanography 24(2): 466-497.

Pérez, F.F., Pollard, R.T., Read, J.F., Valencia, V., Cabanas, J.M. 2000. Climatological coupling of the thermohaline decadal changes in Central Water of the Eastern North Atlantic. Scientia Marina 64(3): 347-353.

ReID, J.L. 1973. The shallow salinity minima of the Pacific Ocean. Deep Sea Research and Oceanographic Abstracts 20: 5168.

Robertson, R., Visbeck, M., Gordon, A., Fahrbach, E. 2002. Long-term temperature trends in the deep waters of the Weddell Sea. Deep Sea Research Part II 49: 4791-4806.

Roemmich, D., Gilson, J., Davis, R., Sutton, P., Wijffels, S., Riser, S. 2007. Decadal spinup of the South Pacific subtropical gyre. Journal of Physical Oceanography 37: 162-173. doi: 10.1175/JPO3004.1.

Roemmich, D., Gilson, J., Sutton, P., Zilberman, N. 2016. Multidecadal change of the South Pacific Gyre circulation. Journal of Physical Oceanography 46: 1871-1883. doi: 10.1175/JPO-D-15-0237.1.

Schneider, W., Fuenzalida, R., Rodríguez-Rubio, E. 2003. Characteristics and formation of Eastern South Pacific Intermediate Water. Geophysical Research Letters 30(11): 1581.

Schneider, W., Fukasawa, M., Garcés-Vargas, J., Bravo, L., Uchida, H., Kawano, T., Fuenzalida, R. 2007. Spin-up of South Pacific subtropical gyre freshens and cools the upper layer of the eastern South Pacific Ocean. Geophysical Research Letters 34: L24606. doi:10.1029/2007/ GL031933.

Schneider, W., Fukasawa, M., Uchida, H., Kawano, T., Kaneko, I., Fuenzalida, R. (2005). Observed property changes in eastern South Pacific Antarctic Intermediate Water. Geophysical Research Letters 32: 1-4. doi: 10.1029/2005GL022801.

Smith, S.D. 1988. Coefficients for sea surface wind stress, heat flux, and wind profiles as a function of wind speed and temperature. Journal of Geophysical Research: Oceans 93(C12): 15467-15472.

Sprintall, J., TomcZAK, M. 1993. On the formation of central water and thermocline ventilation in the southern hemisphere. Deep Sea Research, Part I-Oceanographic Research Papers 40: 827-848.

Stommel, H. 1979. Determination of water mass properties of water pumped down from the Ekman layer to the geostrophic flow below. Proceedings of the National Academy of Sciences of the United States of America 76(7): 3051-3055.

Stramma, L., Peterson, R.G., Tomczak, M. 1995. The South Pacific Current. Journal of Physical Oceanography 25(1): 77-91.

TALLEY, L.D. 1999. Some aspects of ocean heat transport by the shallow, intermediate, and deep overturning circulations. Mechanisms of global climate change at millennial time scales. En: Clark, P.U., Webb, R.S., Keigwin, L.D. (Eds) American Geophysical Union, Washington, D.C. doi: 10.1029/GM112p0001.

Talley, L.D., Pickard, G., Emery, W.J., Swift, J.H. 2011. Physical Oceanography: An Introduction. Elsevier Science \& Technology, UK.

Tomczak, M., Godfrey, J.S. 1994. Regional Oceanography: An Introduction, Pergamon, UK. 422 pp.

Tsuchiya, M., TAlley, L.D. 1998. A Pacific hydrographic section at $88^{\circ} \mathrm{W}$ : Water-property distribution. Journal of Geophysical 
Bombeo de Ekman y Agua Intermedia del Pacífico Sur Oriental: Hernández-VACA F., ET AL

Research 103: 12,899-12,918.

USGODAE Argo GDAC Data Browser. URL http://www. usgodae.org/cgi-bin/argo_select.pl (Accessed: May 5, 2015).

WaUgh, D.W. 2014. Changes in the ventilation of the southern oceans. Philosophical Transactions of the Royal Society of London A: Mathematical, Physical and Engineering Sciences 372(2019): 20130269.

WELLER, R.A. 2015. Variability and trends in surface meteorology and air-sea fluxes at a site off northern Chile. Journal of Climate 28: 3004-3023. doi: 10.1175/JCLI-D-14-00591.1.

Recibido: 18.01 .2017

Aceptado: 25.07.2017 